\section{Flawed physicians}

I used to be obsessed by my flaws: my inability to live up to what I believed was required of me as a doctor. I still believe that medicine is fundamentally a moral enterprise and so what is required of me, even if this sounds hopelessly vague, is to try to do good. Most doctors I know feel the same way. But we also tend to be perfectionists and judge both ourselves and our colleagues by impossibly high standards. We feel we should know everything, never make mistakes, work very hard and be polite and available at all times.

This of course sets the bar very high and is personified in this quote about a well-known doctor:

Visiting him was like chatting with a favourite uncle ... he was a great doctor and very intelligent ... he always had time to talk.... He treated you personally ... he made an effort ... he was not just an overworked doctor who hadn't got time to talk. ${ }^{1}$

What doctor would not covet such a glowing review? The problem is that the doctor in this case is Harold Shipman, Britain's most prolific serial killer ever, who murdered over 250 of his patients during the 1980s and 1990s. This offered some consolation; at least I'm not a psychopath.
But like most people, I could dredge up a long list of flaws: thoughtless husband, inadequate father, mean-spirited friend and even sloppy dresser. As a doctor I didn't know enough, forgot patient's names, was sometimes a poor listener and have made countless mistakes. I avoided unpleasant situations. I lived in a state of constant denial. And on top of everything else, instead of taking responsibility for all my flaws I tended to wallow in the misery of them, to indulge them and to confess them to others, much like I am doing now. It's a kind of lapsed Catholic thing — pathetic self-flagellation.

I couldn't help but compare myself to my physician grandfather and find myself wanting. I never knew him personally, rather, my knowledge of him came through my Auntie Muriel, an elderly spinster who lived by herself in a little house in Dublin, Ireland. When she went out she wore a headscarf, a brown coat and big boots and walked close to the wall. Sometimes you might see her having long intense conversations with other singular women before dashing off to seven o'clock mass; a busy little woman whom you'd

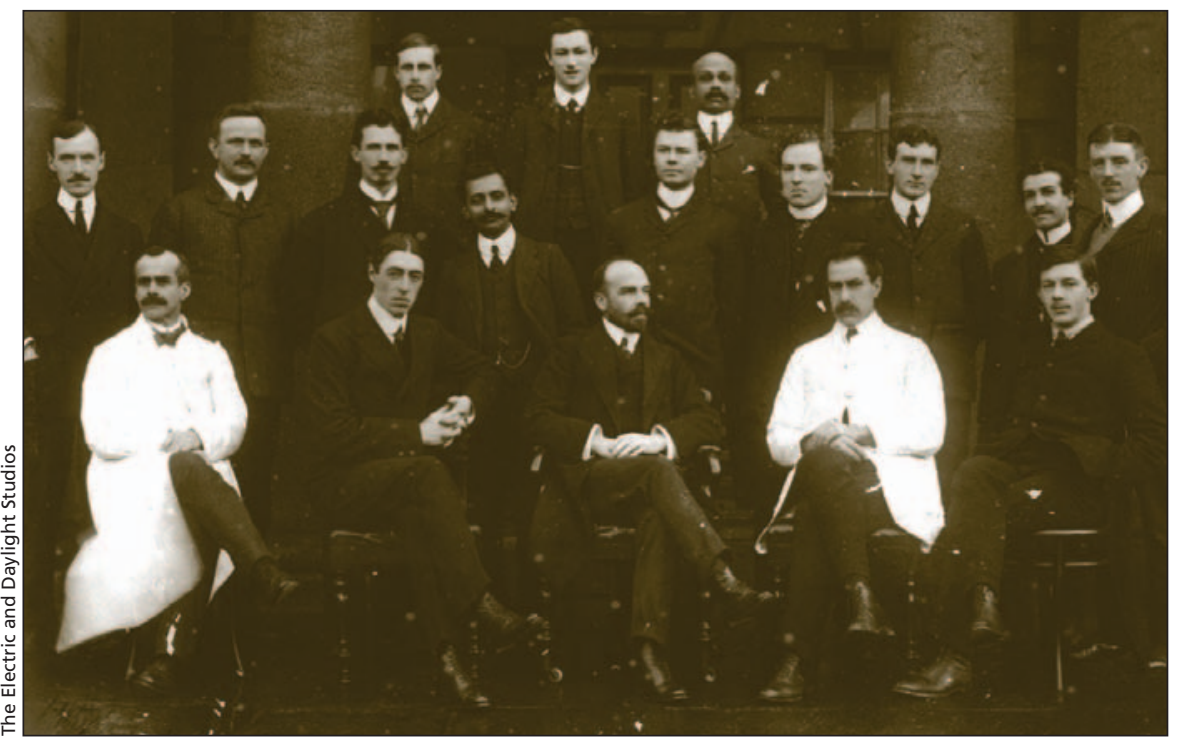

The author combed through family memorabilia for clues about his grandfather Mick's character. In this 1906 photograph, he decided that his grandfather (second row, second from the left) was a sloppy and careless dresser compared with his colleagues at the Rotunda Maternity Hospital in Dublin, Ireland.

hardly notice. She kept a meticulous family archive of anecdotes, scraps of letters, diaries and old photos. And although her stories were inevitably glowing accounts, it is in the close scrutiny of these documents that I hoped to get an objective sense of my grandfather - and maybe his flaws.

I peered at the photograph above my desk of a group of 17 doctors on the steps of the Rotunda Maternity Hospital in Dublin. It was taken in January 1906 and it shows the master of the hospital seated in the centre of the front row surrounded by his assistants. Grandfather Mick is in the row behind him second from the left.

He stands with his shoulders pulled back and his chest pushed forward. He has a round face, short, wiry hair, a large forehead and a moustache. Although his starched, white collar and tie appear to fit comfortably, the jacket seems to tell another tale. It is a type of tweed hunting jacket, visibly creased, and the second and fourth buttons have been left open; there is the suggestion of a pot belly pushing through. This sloppy and careless approach to his dress is in stark contrast to his colleagues. They are a dapper, almost dandyish lot, and you can imagine that once the posing for the photo is over they will take out their pocket watches for a brief glance before briskly striding off to important medical business. It is hard to imagine Mick rushing off and being busy. He appears almost out of place amongst these professional Edwardian medical men. If pride in appearance was important in defining their identity it was obviously a low priority for Mick. He has the look of a practical man with some minor business to attend to, perhaps an off-duty policeman or a small farmer who has come up to Dublin for the day.

In fact, he wasn't far removed from the latter. When I was young, Aunt Muriel loved to tell me tales of how her father had abandoned a rural idyllic farming life to become a doctor. He came up to Dublin and part of his training was to work in tenements 
delivering babies. This was his vocation and she described him as being almost a saint. In my young imagination he would miraculously appear in the crowded room of a desperate Dublin slum, then amidst the grime and the squalor he would present a grateful young mother - bathed in a glow of white light — with a beautiful young baby. I was not so much interested in the banal factual accounts of what he did, but I was fascinated by the moral goodness of the outcome: no flaws on this young doctor.

Then when he was finished with birthing babies he returned to rural Limerick to establish himself as a dispensary doctor. He married and had a family of 4 girls (my aunt assured me that 1 died from eating a rotten apple) and a boy. A photo from this time with Mick sitting off to the side and Aunt Muriel second from the left shows them as a dour family, almost Chekovian in their provincialism.

According to Aunt Muriel he continued, if not to actually perform miracles, then to do saintly Doctor Work. By day he ministered to the sick and indigent, and by night there would be knocks on the back door. Whether it was the Black and Tans or the IRA, Mick would have to go out and treat them. Then when he was worn out by years of medical servitude he retired to the seaside town of Ballybunion where Auntie Muriel looked after him for the rest of his days. And when his days ran

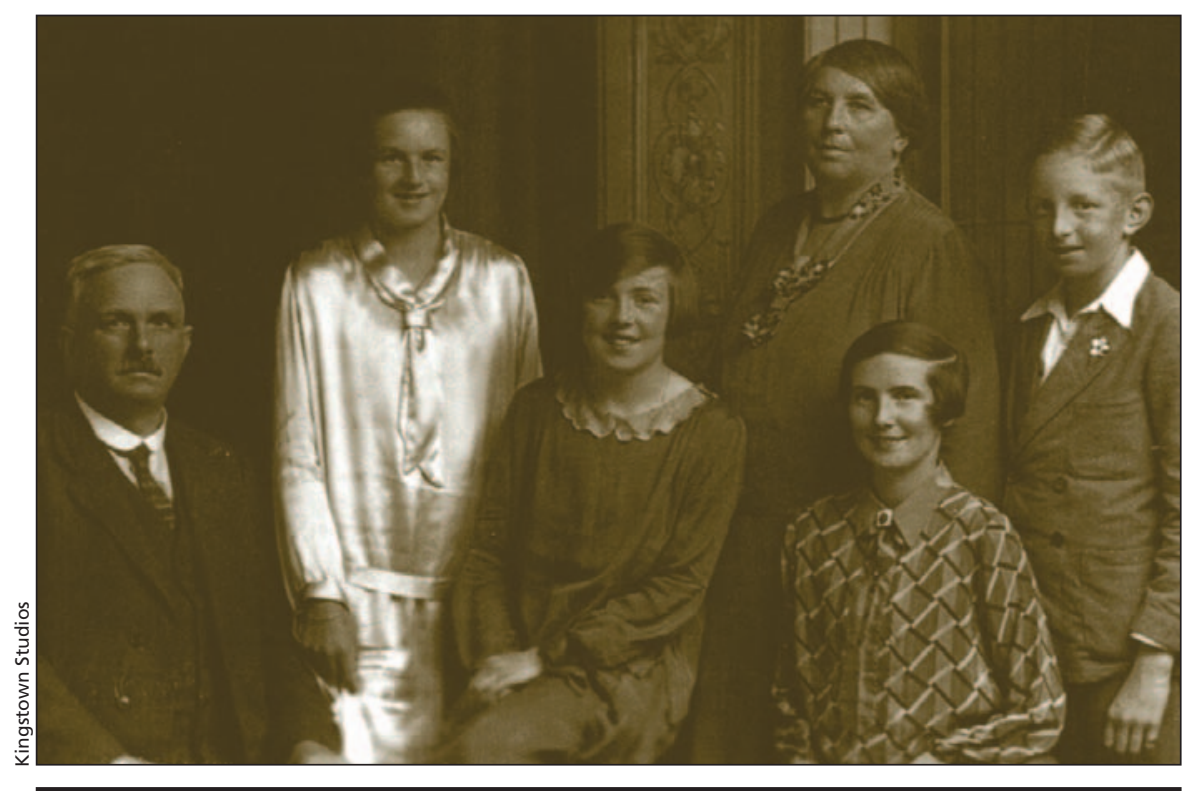

A dour lot, decided the author upon viewing this 1925 family photo, which includes (left to right) Dr. Michael (Mick) E. Cussen, daughters Josie and Muriel, Mrs. Mary Cussen, daughter Flo, and son John Joe (the author's father).

being treated for diabetes, has got a turn for the worse, and his leg has to be amputated to-morrow. With God's help the operation will be successful. It appears that after he was diagnosed he foolishly started prescribing for himself, and begun to cut down on Insulin. About three weeks ago, his son John was in his bedroom and quite accidently noticed that two or three of his toes were discolored. Being a medical student, John knew at once what that meant. And when he challenged his father with being remiss,

\section{He continued, if not to actually perform miracles, then to do saintly Doctor Work.}

out all that was left of him was a silver tea set and a wooden leg.

The tea set was a gift from grateful patients and the wooden leg was a replacement for his real one. I was shocked to learn that he had not lost it in the great fight for Irish freedom, but in the minor battle of personal health. This was revealed in an extract from a diary that one of his nephews kept:

"Got bad news to-day from John Joe Cussen. Uncle Mick who is at present in Richmond Hospital, Dublin the reply he got was, 'My daughter is dead; my wife is dead; my brother is dead, and sure I've got nothing to live for.' John prevailed on him to go to Dublin for treatment, and for the last few weeks the doctors in the Richmond have been fighting to save his leg, but apparently have failed. We are all anxiously awaiting the result of the operation to-morrow"

The operation turned out to be a success. And although Aunt Muriel had convinced me that Mick was a saint, I realized she was a biased narrator. The way I saw it, his sloppy dressing may have been venial, his self-prescribing was a mortal sin (as Osler said, "A physician who treats himself has a fool for a patient.") and his penchant for wallowing in self pity was grounds for eternal medical damnation.

Well, at least that is the way I used to see it. Like many young doctors I tended to be a medically correct brat and an unforgiving moralist, believing that medicine, like religion, is black and white, saint or sinner, "good doctors" or bad apples. But as I've grown older I have tried to kick the judgmental habit, as perhaps my worse flaw. The lesson that I have learned - exemplified by my grandfather — is that life is a constant struggle against our imperfections and none of us is without flaws.

Michael Cussen MID

Hants Shore Community Health Centre Newport, NS

\section{REFERENCE}

1. Whittle B, Ritchie J. Harold Shipman: prescription for murder. New York City: A Time Warner Paperback; 2000.

This article is an excerpt from

Dr. Cussen's memoir-in-progress. 